\title{
Conjugation in Chemostat Cultures of Schizosaccharomyces pombe
}

By I. J. MCDONALD, G. B. CALLEJA AND BYRON F. JOHNSON

Journal of General Microbiology (1982), 128, 1981-1987

Fig. 3, p. 1986:

The scale on the ordinate of the small graph on the right should be numbered $10,30,50,70$ and not $10,30,70,90$.

Interrelationships Between Physical State, Phenotypic Stability and Transferability of $\beta$-Lactamase Genes in Haemophilus influenzae

By JOHN E. WILLARD, EMMETT J. JOHNSON AND ROBERT S. DAUM

Journal of General Microbiology (1982), 128, 2353-2360

p. 2353, Summary, lines 6-7:

for 'Of 23 plasmids that were unstable in vitro, $10(43 \%)$ had molecular weights of $30 \times 10^{6}$ and coded only for $\beta$-lactamase' read 'Ten of $23(43 \%)$ plasmids were unstable in vitro, had molecular weights of $30 \times 10^{6}$ and coded only for $\beta$-lactamase.' 